\title{
MAATALOUTEEN LIITTYVIEN ETUUKSIEN ARVIOIMISESTA TOISTA KORVAUSLAKIA SOVELLETTAESSA.
}

\author{
Antti MäKI. \\ Yliopiston maanviljelystaloudellinen laitos, Helsinki. \\ Saapunut 22. 2. 1950.
}

Toukokuun 5 päivänä 1945 annettua toista korvauslakia samoin kuin vuosien 1940 ja 1942 korvauslakeja sovellettaessa luettiin korvattavaan omaisuuteen myös tulo- ja omaisuusverolaissa mainitut nautintaoikeudet ja oikeudet tuottoon tai muuhun etuuteen sekä lisäksi eräitä omaisuusosia, joita ei ole sisällytetty muihin maatalouskiinteistöön kuuluviin pääomiin. Kun tähän ryhmään kuuluvilla omaisuusosilla saattaa olla maatalouteen liittyvinä etuuksina erittäin suuri taloudellinen merkitys, ja niiden arvon määrittäminen muodostaa mielenkiintoisen, mutta kirjallisuudessa odottamattoman vähän kosketellun osan maatalouden arvioimiskysymyksistä, käsitellään seuraavassa eräitä tälle alalle kuuluvia arvioimistehtäviä lähinnä toista korvauslakia sovellettaessa saatujen kokemusten ja sen yhteydessä tehtyjen ratkaisujen perusteella $(6$, s. $36-37)$.

\section{Yleiset perusteet etunksien arvioimisessa.}

Tulo- ja omaisuusverolaki vuodelta 1924 (17 §) samoin kuin myös vuodelta 1943 (37 §) edellyttävät, että etuuksien arvo on yleensä määritettävä niistä saatujen vuositulojen perusteella. Milloin etuus on voimassa rajattoman ajan, pääomitetaan siitä saatu vuotuinen puhdas tuotto $5 \%$ :n korkokannan mukaan, jolloin saadaan etuuden pääoma-arvo. Puhdasta tuottoa laskettaessa on kokonaistuotosta vähennettävä kaikki muut tuoton hankkimisesta aiheutuneet kustannukset paitsi pääomien korkokustannusta. Kun toista korvauslakia sovellettaessa oli seurattava tulo- ja omaisuusverclain säännöksiä, jouduttiin edellä mainittua laskutapaa ja $5 \%: n$ korkokantaa tietenkin käyttämään tämänlaatuisten, rajattoman ajan kestävien etuuksien arvoa määritettäessä. Tätä laskutapaa joudutaan käyttämään usein myös silloin, kun »etuus» on negatiivista laatua esiintyen puutteellisuutena, 
jonka korjaamiseen maatalouskiinteistön on vuosittain uhrattava varoja. Jos esim. tila joutuisi vuosittain maksamaan naapuritilalle korvausta vedenottopaikasta, jollaista ei arvioitavalla tilalla ole, on tällaisen rasituksen vuotuissumma pääomitettava ja otettava saatu pääoma-arvo huomioon tilan kokonaisarvoa vähentävänä tekijänä. Yleistettynä voidaan rajattoman ajan kestävän tuoton tai haitan pääoma-arvo laskea kaavasta:

$$
K=\frac{r}{0.0 p},
$$

jossa $K=$ etuuden tai haitan pääoma-arvo, $r=$ vuotuinen puhdas tuotto ja $p=$ korkosadannes.

Kun tulo- ja omaisuusverolaki säätää etuuksien arvioinneissa käytettäväksi $5 \%$ :n korkosadannesta, saadaan etuuden pääoma-arvo yksinkertaisimmin kertomalla vuotuinen puhdas tuotto kahdellakymmenellä.

Huomattavasti useammin kuin rajattoman ajan kestävät etuudet tulevat maataloudessa ja myös toista korvauslakia sovellettaessa kys̉ymykseen määrävuosia kestävät etuudet. Jos on kysymyksessä elinkautinen nautintaoikeus tai muu etuus, on sen arvo määritettävä, jos siihen oikeutettu henkilö on iältään alle 16 vuotta, vuositulon 18-kertaiseen määrään, 16-25 vuotta, vuositulon 17-kertaiseen määrään, 26 - 35 vuotta, 16 -kertaiseen määrään jne., kunnes 81 vuotiaan tai sitä vanhemman henkilön nauttiman etuuden arvo on laskettava vuositulon 2-kertaiseen määrään. Nämä tulo- ja omaisuusverolakiin otetut kertoimet, joita ei sanottavasti jouduttu käyttämään toista korvauslakia sovellettaessa, koska ihmisikään sidottuja, korvauksenalaisia etuuksia esiintyi sangen harvoin, perustuvat tilastollisiin selvityksiin eri-ikäisten henkilöiden jäljellä olevasta keskimääräisestä elinajasta ja rajoitetun ajan kestävän tuoton pääoma-arvon määrittämisessä käytettyyn laskutapaan.

Määrävuosia kestävä etuus on tulo- ja omaisuusverolain säännösten mukaan arvioitava siihen pääoma-arvoon, mikä sillä on, laskettuna etuuden voimassaoloajasta jäljellä olevien täysien vuosien luvun ja viittä sadalta vastaavan korkokannan mukaan. Pääoma-arvo saadaan kaavasta, joka yleisessä muodossaan voidaan johtaa geometrisen sarjan summasta diskontoimalla $n$ vuoden kuluessa erääntynyt pääoma-arvo arvioimishetkeen seuraavalla tavalla:

$$
K=\frac{r}{0.0 p} \cdot \frac{\left(1.0 p^{n}-1\right)}{1.0 p^{n}}=\frac{r}{0.0 p} \cdot\left(1-\frac{1}{1.0 p^{n}}\right)=\frac{r}{0.0 p}-\frac{\frac{r}{0.0 p}}{1.0 p^{n}},
$$

jossa $K=$ etuuden pääoma-arvo, $p=$ korkosadannes ja $n=$ vuosien luku.

Verotuslautakuntien työn helpottamiseksi samoin kuin arvioimislautakuntienkin tarpeiksi on käytettävissä valmiiksi laskettuja kertoimia, joilla $5 \%$ :n korkokantaa käytettäessä vuotuinen puhdas tuotto on kerrottava pääoma-arvon saamiseksi. - Erittäin yleisenä virheenä korvaushakemuksissa ja niiden johdosta annetuissa lausunnoissa esiintyi etuuksien arvon määrittäminen siten, että esim. myyntikelpoisen tuotteen yksikkömäärällä kerrotaan yksikön hinta nykyhetkellä, jolloin 
ei tule huomioon otetuksi etuudesta saatavan vuotuisen puhtaan tuoton suuruus eikä myöskään myyntiajan vaikutus tulevaisuudessa saatavien tuloerien pääomaarvoon arvioimishetkellä.

\section{Maatalousmaan arvoon sisältyvät etundet.}

Vaikka useissa korvaushakemuksissa mainittiin erityisinä etuuksina erilaiset maatalouteen liittyvät maanparannusaineiden ottopaikat, joita tilalla oli omaa tarvetta varten käytettävissä, on ne käsitettävä "normaaliin» maatalouteen kuuluviksi, jollaisina niille ei ole määritettävä erityistä arvoa, vaan niiden arvon on katsottava sisältyvän maatalousmaan keskimääräiseen hintaan. Vieläpä tähän ryhmään on luettava sellaisetkin toiseen kiinteistöön kohdistuvat oikeudet, joita isossajaossa ja tiloja ositettaessa voidaan perustaa ja joita ovat: oikeus tiehen, karjanajoon, vesipaikkaan, veden johtamiseen tai patoamiseen, venevalkamaan sekä kalastusta varten tarpeelliseen maahan. ${ }^{1}$ Muita kuin äsken mainittuja rasiteoikeuksia ei enää saa jakotoimituksissa määrätä. Rasiteoikeus voi syntyä myöskin oikeustoimen tai välipuheen nojalla tai se voi syntyä ylimuistoisen nautinnan johdosta. Tällaisia rasitteita voivat olla esim. oikeus ottaa toisen tilan maalta määräpaikasta kiviä, soraa, savea, turpeita tms. Kun kaikki edellä mainitut etuudet ovat yleer.sä välttämättömänä edellytyksenä tilan jatkuvalle, tarkoituksenmukaiselle käytölle ja maatalouden harjoittamiselle, eikä etuuksista aiheudu tilalle lisätuloja, ei niiden arvoa ole myöskään syytä ottaa erikseen huomioon tilan arvoa määritettäessä. Päinvastaisessa tapauksessa, jolloin tilalta punttun joku sen hoidolle välttämätön edellytys, on tästä aiheutuva haitta otettava vähennyksenä huomioon ja määritettävä tilan arvo alhaisemmaksi, kuin mitä se olisi keskimääräistä hintatasoa noudattaen. Miten tällaisen puutteellisuuden arvo olisi määritettävä, riippuu olosuhteista. Jos puute voidaan korvata kertakaikkisella toimenpiteellä, esim. rakentamalla välttämätön tie, on tästä aiheutuvat kustannukset vähennettävä tilan pääoma-arvosta. Jos haitan poistaminen aiheuttaa vuotuisia kustannuksia, on laskettava kustannusten pääoma-arvo. Jos taas haitta on senlaatuinen, ettei sitä voida lainkaan poistaa, vaan sen vaikutus ilmenee esim. satotulosten alenemisena, on tämä tuoton vähennys pääomitettuna otettava huomioon kiinteistön arvoa määritettäessä. Aina ei voida suoraan arvioida, kuinka suuri olisi esim. kuivikkeina käytettävän turvepehkun puutteesta aiheutuvan haitan pääoma-arvo johonkin toiseen tilaan verrcttuna, vaan on turvauduttava verrannollisten 1 . suhteellisten arvojen käyttöön laskemalla, paljonko haitan poistaminen tulisi maksamaan muita kuivikkeita käyttäen.

Maataloudessa esiintyy myös ryhmä »etuuksia», joista on tilalle suoranaisia tuloja, mutta joita siitä huolimatta ei voida erikseen lisätä maatalouspääomien arvoon. Tällaisia ovat erilaisista haitoista maksettavat korvaukset, jotka usein esitetään positiivisina etuuksina. Jos esim. sähkö- tai puhelinlinja joudutaan vetämään tilan maiden halki, maksetaan tästä aiheutuvasta haitasta tilalle korvausta joko rahana

1 Asetus jakolaitoksesta 26 päivältä lokakuuta $1916,16 \S$. 
tai esim. ilmaiseksi saatavan sähkövirran muodossa. Mikäli kuitenkaan korvaus ei ole suurempi kuin vuotuisen haitan on arvioitu olevan, ei tällaista erää voida pääomitettuna ottaa erikseen huomioon, ellei maan arvoa vähennetä vastaavalla summalla korvauksen kohteena olevan toimenpiteen aiheuttaman haitan tähden. Tähän ryhmään voidaan lukea myös eräät tilan alueen käytöstä saadut vuokratulot, kuten esim. korvaukset ranta-alueen käytöstä puutavaran säilytykseen tai lastauspaikaksi tai tilalle maksetut korvaukset lauttauksen tuottamista haitoista. Tietenkin voi olla tapauksia, joissa vuotuinen tulo on suurempi kuin haitan arvioidaan olevan ja jolloin osa vuokrasta on sisällytettävä tuloa tuottaviin etuuksiin. Jos esim. ranta-alueesta saadaan lastauspaikkana tuloa enemmän kuin mitä vastaavan alueen arvo olisi laitumeksi käytettynä, eikä vuokrauksesta aiheudu muita haittoja, on tällaisen lisätulon määrä pääomitettuna lisättävä etuuksien arvoon tai arvioitava lastauspaikka, jos se on pysyväinen, omana maankäyttölajinaan. Alueiden käyttöä ja siitä saatavaa tuloa arvioitaessa on kuitenkin otettava huomioon kaikki kysymykseen liittyvät tekijät, joista osa voi olla taloudelliselta arvoltaan vaikeasti määritettävissä.

\section{Tuloa tuottavat etundet.}

Edellä mainittujen maatilan arvoon sisällytettävien etuuksien lisäksi liittyy maatiloihin joukko sellaisia etuuksia, joista tilalle aiheutuu tuloa verrattuna muihin vastaavanlaisiin kiinteistöihin, ja jotka on otettava erikseen huomioon maatalouspääomien arvoa määritettäessä. Tällaisia ovat eräät tiloihin liittyvät oikeudet, kuten esim. oikeus koskivoimaan tai kalastuksen harjoittamiseen, joita ei tässä yhteydessä lähemmin käsitellä, tai oikeus laiduntamiseen toisen henkilön omistamalla alueella. Tällaisissa tapauksissa on laskettava etuuden tuottama vuotuinen puhdas tuotto. Riippuen siitä, onko oikeus jatkuva, eliniän vaiko määrävuodet kestävä, on vuotuinen puhdas tuotto pääomitettava käyttäen edellä esitettyjä laskutapoja.

Edellistä tärkeämmän ryhmän muodostavat ne etuudet, jotka perustuvat erilaisten tarveaineiden tai tonttialueiden myyntiin ja joista voi aiheutua tilalle jatkuvia, vuotuisia rahatuloja. Tällaiset etuudet voivat olla taloudellisesti erittäin arvokkaita ja niistä saatava vuotuinen tulo saattaa useissa tapauksissa kohota kiinteistön omistajan muita tuloja korkeammaksi.

Tuloa tuottavina etuuksina voidaan mainita ensi sijassa mahdollisuudet myydä tilan alueelta soraa, hiekkaa, kiveä, savea, mutaa, polttoturvetta, turvepehkua tms. Lisäksi voi tilalla olla lukuisia kivennäisesiintymistä aiheutuvia etuuksia, kuten mahdollisuus myydä kaoliinia, maasälpää, kvartsia ym. puhumatta tässä yhteydessä lainkaan mahdollisuuksista varsinaiseen kaivostoimintaan.

Erittäin tärkeänä etuuksien muotona on lopuksi mainittava mahdollisuus myydä tonttialueita, joiden kysyntä vuosi vuodelta on lisääntymässä ja joiden arvo saattaa muodostaa erittäin tärkeän omaisuusosan maatalouskiinteistön pääomaarvoa määritettäessä. 
Kun kaikkien edellä mainittujen ja lukuisten muiden etuuksien yksityiskohtainen käsittely ei ole tarpeellista, koska niiden arvioimisessa on noudatettava pääpiirtein samoja menetelmiä, käsitellään seuraavassa vain esimerkin luontoisina eräitä tähän liittyviä arvioimiskysymyksiä sellaisina kuin ne yleisemmin esiintyivät toista korvauslakia sovellettaessa.

Mahdollisuus myydä tilan alueelta soraa tai hiekkaa on etuus, joka on hyvin tavallinen varsinkin asutuskeskusten läheisyydessä ja hyvien kulkuteiden varsilla. Seuduilla, joissa sorasta ja hiekasta on puutetta, saattaa etäälläkin oleva myyntipaikka muodostua etuudeksi, jonka arvo kohoaa moninkertaiseksi muihin tarkoituksiin käytetyn maan arvoon verrattuna. Soranottopaikat olivat tonttiarvojen ohella myös tavallisimmat niistä etuuksista, joita toista korvauslakia sovellettaessa jouduttiin arvioimaan.

Sora- tai hiekka-aluetta arvioitaessa on ensimmäisenä tehtävänä tietenkin määrittää alueen laajuus ja sorakerroksen keskimääräinen syvyys. Näiden tietojen perusteella voidaan suunnilleen laskea alueella olevan myyntikelpoisen soran tai hiekan määrä. Vielä tärkeämpänä tekijänä etuuden arvoa määritettäessä on otettava huomioon soran tai hiekan keskimääräinen myyntimäärä vuotta kohden. Milloin on kysymyksessä vuotuiseen myyntimäärään verrattuna suuri alue, josta soraa tai hiekkaa riittää myytäväksi käytännöllisesti katsoen rajattoman pitkäksi ajaksi, ei ole lainkaan tarpeellista ryhtyä laskemaan alueella olevan hiekan tai soran kokonaismäärä, koska alueen arvo määräytyy yksinomaan vuotuisten myyntimäärien ja saatavien yksikköhintojen perusteella.

Kun tunnetaan sora-alueen pinta-ala ja sorakerroksen syvyys, voidaan laskea alueella oleva kokonaissoramäärä. Näin saatu luku ei kuitenkaan osoita myyntikelpoisen soran määrää, koska tilavuuteen sisältyy aina jonkin verran peitemaata, suurempia kiviä yms., joiden määrä voi olla 10, 20 jopa $30 \%$ soran lasketusta kokonaismäärästä. Lisäksi voi alueella olla kerrostumia, jotka eivät laatunsa puolesta kelpaa tavallisiin soran tai hiekan käyttötarkoituksiin. Kun tällaiset kerrostumat samoin kuin peitemaa ja kivet tuottavat ainoastaan haittaa sora-alueen käytölle, ei niiden tilavuutta voida ottaa huomioon sora-alueen arvoa määritettäessä. Jos on kysymyksessä suhteellisen ohut ja laaja soraesiintymä, osoittaa esiintymän kokonaistilavuus, josta on vähennetty käyttökelvottomien ainesten määrä, myyntikelpoisen soran tai hiekan määrän. Jos sitä vastoin soraesiintymä on syvä, sisältäen soraa ja hiekkaa esim. 20-30 metrin vahvuisena kerroksena, antaa alueen pintaalan ja sorakerroksen paksuuden perusteella laskettu luku virheellisen ja harhaanjohtavan kuvan alueella olevan, myyntıkelpoisen aineksen määrästä. Tämä aiheutuu siitä, ettei tietyltä alueelta voida ilman erittäin kalliita lisätoimenpiteitä poistaa pystysuorien sivujen ja sorakerroksen pohjapinnan rajoittaman kappaleen sisältämää ainesmäärää, vaan soran luonnollinen kaltevuus vaikuttaa, että soranottopaikan seinämille joudutaan jättämään sitä suurempi määrä soraa, mitä paksumpi sorakerros on alueen laajuuteen verrattuna. Teknillisen käsikirjan (8, s. 671) antamien tietojen mukaan on luonnollisen luiskan ja vaakasuoran välinen kulma eri maalajeilla seuraava: 


$\begin{array}{lr}\text { kuiva savensekainen hiekka } & 40-50^{\circ} \\ \text { märkä " } & 20-25^{\circ} \\ \text { märkä hiekka } & 25^{\circ} \\ \text { märkä sora } & 35-40^{\circ}\end{array}$

Soran luonnollinen kaltevuus, johon sorakerros pyrkii asettumaan, on siten verrattain loiva, mikä seikka on ehdottomasti otettava huomioon myyntikelpoisen soramäärän paljoutta arvioitaessa. Jos esim. luonnollinen kaltevuus olisi $35^{\circ}$, on tämän kulman tangentti 0.70021 ja cotangentti 1.42815 , mikä merkitsee, että esim. 10 metrin korkuiselle seinämälle jäävä soramäärä ulottuu 14.28 metrin etäisyydelle seinäviivasta ja sorakuopan vastakkaisten seinämien tulisi olla vähintään 28.56 metrin etäisyydellä toisistaan, ennen kuin alueen keskikohdalta voitaisiin ottaa soraa 10 metrin syvyydeltä. Koko soramäärä muodostaisi tässä tapauksessa likimäärin särmäkartiomaisen (pyramiidimaisen), ylösalaisin olevan kappaleen, jonka pohjan pinta-ala on yhtä suuri kuin sora-alueen pinta-ala, ja korkeus 10 metriä, joten poistettavaksi mahdollisen soran määrä on särmäkartion tilavuussäännön mukaan kolmasosa alueella olevasta kokonaissoramäärästä. Tästä olisi edelleen vähennettävä peitemaan, kivien yms. osuus. Laskelma osoittaa, että myyntikelpoisen soran määrä tulisi tällaisessa tapauksessa olemaan ainoastaan n. $20-25 \%$ siitä määrästä, joka saadaan kertomalla sora-alueen pinta-ala sorakerroksen korkeutta osoittavalla luvulla.

Vaikka edellä esitetty esimerkki sora-alueen mittasuhteista näyttää teoreettiselta, esiintyi korvaushakemuksien yhteydessä pinta-alaltaan pieniä, mutta $20-30$ metrin syvyisiä sora-alueita, joita ei todellisuudessa olisi voitu ilmoitettuun syvyyteen asti käyttää ilman, että soranottopaikka olisi samalla laajentunut rajanaapureiden alueille. Syviä soranottoalueita arvioitaessa on otettava huomioon myös pohjaveden korkeus, joka usein tekee mahdottomaksi sora-alueen hyväksikäytön koko syvyydeltään.

Tavallisesti soranottopaikka on edellä esitettyä laajempi sorakerroksen vahvuuteen verrattuna. Jos alue on neliön tai suorakaiteen muotoinen, muodostuu käyttökelpoisesta soramäärästä tässä tapauksessa likimäärin katkaistun särmäkartion muotoinen kappale, jonka pohjapintana on sora-alueen pinta maanpinnan tasossa ja yläpintana soranottopaikan pohjalle muodostuva pinta.

Katkaistun särmäkartion tilavuus saadaan likimääräisesti seuraavasta kaavasta:

$$
\mathrm{V}=\mathrm{h} \times \frac{\mathrm{A}_{1}+\mathrm{A}_{2}}{2},
$$

jossa $\mathrm{V}=$ tilavuus, $\mathrm{A}_{1}$ ja $\mathrm{A}_{2}=$ pohja- ja yläpintojen pinta-alat sekä $\mathrm{h}=$ korkeus. Tarkempi tulos saadaan kaavasta

$$
\mathrm{V}=\frac{1}{3} \mathrm{~h} \times\left(\mathrm{A}_{1}+\sqrt{\mathrm{A}_{1} \mathrm{~A}_{2}}+\mathrm{A}_{2}\right)
$$

jossa kirjaimet merkitsevät samaa kuin edellä. Jälkimmäinen kaava on matemaattisesti oikea, mutta edellinen riittää hyvin sellaisen tarkkuuden saavuttamiseen, joka on mahdollista muiden sora-alueen arvoon vaikuttavien tekijöiden määrittämisessä. 
Niinkuin mainittiin, on edellä selostetun laskutavan käyttö välttämätöntä arvioitaessa tavallista syvempiä hiekka- tai sora-alueita, joita maassamme korvausanomuksista päätellen esiintyy sangen runsaasti. Pääasiana on, että myyntikelpoisen soran määrää arvioitaessa otetaan huomioon ainoastaan todella käyttö- ja siirtokelpoinen aines.

Paitsi soran tai hiekan määrä ja keskimääräisen vuosimyynnin suuruus on soraalueen arvoa laskettaessa tunnettava sora- tai hiekkakuutiometrin keskimääräinen nettohinta, jota määritettäessä on sora-alueen hoitokulut ym. myyntikustannukset kokonaismyyntihinnasta vähennettävä. Kun edellä olevat tekijät tunnetaan, voidaan alueen arvo laskea edellä esitetyillä laskutavoilla. Jos alue on erittäin laaja tai soramäärä suuri vuosikulutukseen verrattuna ja soraa tai hiekkaa riittäisi esim. 60-100 vuoden ajaksi, voidaan alueen arvo suurta virhettä tekemättä laskea (5\% korkokannan mukaan) kertomalla vuotuinen puhdas tuotto luvulla kaksikymmentä, ts. edellyttämällä tuoton jatkuvan rajattoman pitkän ajan. Kerroin, jolla vuotuinen puhdas tuotto rajoitetun ajan kestävää tuottoa laskettaessa olisi kerrottava, kun korkokanta on $5 \%$, on 60 vuoden kohdalla 18.93, 70 vuoden kohdalla 19.34, 80 vuoden kohdalla 19.60 ja 100 vuoden kohdalla 19.85 , joten näiden lukujen asemesta voidaan käyttää kerrointa 20 ilman että virhe tulee muita todennäköisiä arvioimisvirheitä suuremmaksi.

Jos sitä vastoin voidaan edellyttää, että alueella riittää soraa tai hiekkaa arvioimisajan kulutuksen mukaan arvioituna lyhyemmäksi ajaksi, esim. 20, 30 tai 40 vuodeksi, on vuotuisen puhtaan tuoton pääoma-arvo laskettava käyttäen edellä esitettyä rajoitetun ajan kestävän tuoton pääomittamistapaa tai valmiiksi laskettuja kertoimia (ks. s. 58). Tulevaisuudessa saatavien tulojen diskontaus arvioimishetkeen vaikuttaa, ettei esim. 40 vuoden aikana saatavien tulojen nykyarvo ole 40-kertainen vuositulon määrä, vaan ainoastaan 17.16-kertainen. Korkein arvo, mikä tämäntapaisella etuudella voi olla, saadaan pääomittamalla vuotuinen puhdas tuotto rajattoman ajan kestävänä, ts. kertomalla se $5 \%$ :n korkokantaa käytettäessä kahdellakymmenellä, 6\%:n korkokantaa käytettäessä 16.67:llä jne. Tämä erittäin tärkeä tosiseikka näyttää jääneen useimmille korvauksen hakijoille, vieläpä teknillistä tietoa omaaville henkilöillekin täysin tuntemattomaksi ja etuuksien arvo on laskettu kertomalla myytävän tuotteen yksikköhinta yksiköiden kokonaismäärää osoittavalla luvulla, jolloin on jouduttu täysin todellisuuspohjaa vailla oleviin tuloksiin. Samalla on tehty eräs suurimmista virheistä, joita maatalouteen liittyvissä arvioimiskysymyksissä voidaan pitää mahdollisina.

Kirjoittaja on havainnut eräissä sora-alueiden pakkolunastusta koskevissa asioissa esitettävän, että suurten sora-alueiden ollessa kysymyksessä ne olisi arvioitava alueen pinta-alan eikä sillä olevan soran kuutiometrimäärän perusteella. Tämä vaatimus johtuu kirjoittajan käsityksen mukaan siitä, että sorakuutiometrimäärään perustuva laskelma on laadittu virheellisesti ottamatta huomioon edellä tähdennettyä myyntiajan vaikutusta. Pinta-alan edellyttämä arviointi taas perustuu vastaavanlaisista alueista maksettuihin kauppahintoihin, joissa myyntiajan vaikutus tulee huomioon otetuksi ilman, että arvion tekijät sitä tietoisesti tarkoittavat. Mikäli arviointi suoritetaan teoreettisesti moitteettomalla tavalla, tullaan yhtäpitä- 
vään tulokseen, käytettäköönpä soran ja hiekan ottopaikkojen ja muiden tähän verrattavien alueiden arvioinneissa perustana alueen pinta-alaa tai siinä olevan myyntikelpoisen aineksen määrää.

Edellä esitetyt periaatteet soveltuvat useiden sellaisten etuuksien arvon määrittämiseen, joissa etuus perustuu maan, kiven, turpeen tms. myyntiin. Kaikissa tapauksissa on tunnettava myyntikelpoisen tuotteen määrä, yksikköhinta ja tuotteen keskimääräinen vuotuinen menekki. Näiden tekijöiden määrittämiseen liittyy eri tuotteiden kohdalla lukuisia yksityiskohtia, joista muutamia seuraavassa mainitaan.

Hyvin tavallisen etuuden luovutetuilla alueilla muodostivat tiiliteollisuuden raaka-aineena käytettävät savialueet sekä ns. kambrista savea sisältävät alueet, jotka muodostavat n. 12-15 m paksun kerrostuman suurella osalla koko Karjalan kannasta (7, s. 35). Kambrista savea käytetään klinkkeriteollisuudessa haponkestävien laattojen, muototiilien, putkien ja astioiden sekä seinien ulkopeitteenä käytettävien levyjen valmistamiseen. Kun kambrisella savella oli jonkin verran menekkiä ja siitä maksettiin huomattava hinta, n. mk 20:- kuutiometriltä, on ymmärrettävissä, että suure+kin savialueet tulivat merkityksi etuuksiksi, joiden arvo määritettiin kertomalla yksikköhinta saven kuutiometrimäärällä. Näin jouduttiin kuitenkin täysin virheellisiin tuloksiin, sillä kambrisen saven kokonaiskulutus maassamme oli ennen sotia n. 2.000 tonnia vuodessa (7, s. 35), joten vuotuinen kulutus olisi saatu tyydytetyksi n. yhden aarin alalta. Kun raaka-aineen määrä on melkeinpä rajattoman suuri sen kulutukseen verrattuna, on tällaisen tuotteen myynnistä aiheutuvan etuuden arvo ehdottomasti määritettävä pääomittamalla myynnistä aiheutuva vuotuinen keskimääräinen puhdas tuotto. Käyttämällä lähtökohtana saven kokonaismääriä ja kuutiometrin yksikköhintoja joudutaan täysin harhaanjohtaviin tuloksiin.

Savialueella voi olla erityistä arvoa tiiliteollisuuden raaka-aineena joko siten, että lähellä sijaitseva tiilitehdas hankkii savea ostamalla tai tilalla on oma tiilien valmistuslaitos. Edellisessä tapauksessa on tavallisesti olemassa vuokrakirja tai kauppakirja, josta saadaan lähtökohta etuuden arvon määrittämiseksi. Tärkeintä on tässäkin tapauksessa tuntea saven vuotuinen menekki ja siitä saatava keskimääräinen nettohinta. Pieniä savialueita arvioitaessa on lisäksi välttämättä tunnettava käyttökelpoisen saven kokonaismäärä. Poistettavan savikerroksen paksuudesta tavallisesti riippuu, mikä arvo alueelle on annettava savikerroksen käytön jälkeen. Jos savikerros on ohut, voi alue tulla savenoton jälkeen käytetyksi muihin tarkoituksiin, esim. pelto- tai metsämaana. Joskus menetellään siten, että ostaja poistaa savikerroksen päällä olevan ruokamultakerroksen, käyttää saven sovitulta syvyydeltä ja kuljettaa sen jälkeen ruokamullan paikoilleen, jolloin aluetta voidaan jälleen käyttää maanviljelystarkoituksiin. Kauppaehdoista riippuu, paljonko myydyn saven nettohinnaksi ja etuuden tuottoarvoksi voidaan laskea.

Yhdestä savikuutiometristä lasketaan saatavan n. 333 tiiltä, joten esim. miljoonan tiilen valmistamiseen vuodessa tarvitaan $3.000 \mathrm{~m}^{3}$ savea. Savikerroksen paksuudesta riippuu hehtaarilta saatava määrä, joka hyvillä savialueilla voi kohota yli 100.000 kuutiometrin. Näiden lukujen perusteella voidaan arvioida, kuinka 
pitkäksi ajaksi alueen savimäärä riittäisi, ja ottaa huomioon tämä aika alueen arvoa määritettäessä. Samat perusteet tulevat kysymykseen arvioitaessa omassa taloudessa tehtävien tiilien valmistukseen käytettävän saven määrää. Ottaen huomioon, että ottokustannukset muodostavat raaka-aineena käytettävän saven hinnasta suurimman osan, jää raaka-aineen arvon osuus varsin pieneksi valmiiden tiilien arvoon verrattuna. On laskettu raaka-aineena käytetyn saven arvon olevan n. $2 \%$ tiilien hinnasta. Jos siis maatilan yhteydessä valmistetaan tiiliä pienessä mittakaavassa, muutamia kymmeniä tuhansia, ehkäpä satatuhatta kappaletta vuodessa, muodostuu raaka-aineesta saatava puhdas tuotto ja tästä aiheutuva etuus tavallisesti verraten vaatimattomaksi.

Laajojen savialueiden arvioinnissa on huomattava, että niitä voidaan samanaikaisesti savenoton kanssa muilta osiltaan käyttää esim. tavalliseen peltoviljelykseen, jolloin saven myynnistä aiheutuvan tuoton pääoma-arvo on lisättävä tavalliseen pellon hintaan.

Kun on kysymyksessä savialue, jota todellisuudessa käytetään tai voitaisiin käyttää paikkakunnalla olevan teollisuuslaitoksen raaka-aineen hankkimiseen, perustuu alueen arviointi ainakin pääkohdiltaan olemassa oleviin tosiseikkoihin ja niiden vaikutukseen alueen arvon muodostumisessa. Toisin voi olla asianlaita sellaisessa tapauksessa, jossa savialue tai muu vastaavanlainen alue soveltuisi teollisuuden raaka-aineen hankintaan käytettäväksi, mutta tällaista laitosta ei paikkakunnalla ole olemassa. Jos kaikissa tämänlaatuisissa tapauksissa alueet arvioitaisiin sen perusteella, mihin niitä tulevaisuudessa mahdollisesti voitaisiin käyttää, jouduttaisiin ilmeiseen mahdottomuuteen. Kun esim. savea on maassamme siksi runsaasti, että tiiliteollisuutemme raaka-aineen saanti on turvattu epämääräisen pitkäksi ajaksi eteenpäin, ei voida antaa mitään erikoisarvoa kaikille niille alueille, joita tähän tarkoitukseen voidaan käyttää. Sen tähden on yleensä noudatettava suurta varovaisuutta tämänlaatuisten etuuksien arvioimisessa ja otettava alueesta saatava lisätuotto huomioon vain sellaisessa tapauksessa, jossa jo on olemassa todelliset mahdollisuudet alueen sisältämän raaka-aineen käyttämiseen.

Eräänä erikoiskysymyksenä varsinkin sora- ja hiekka-alueiden, mutta myös muiden myyntikelpoista ainesta sisältävien alueiden arvon määrittämisessä tulee kysymykseen niitä varten rakennettujen teiden hinnoittaminen. Tien rakennuttaminen on saattanut tulla varsinkin autokuljetuksen vaatimuksia silmällä pitäen huomattavan kalliiksi ja korvaushakemuksissa oli ymmärrettävissä, että tällainen pääoman sijoitus merkittiin korvattavan omaisuuden luetteloon sen alueen arvon lisäksi, jota varten tie oli rakennettu. Kysymystä lähemmin tarkastettaessa on kuitenkin todettava, että tie on välttämätön edellytys raaka-ainealueen käyttämiseksi ja ilman myyntimahdollisuuksia alueella ei olisi mitään erityisarvoa. Sen tähden on alue ynnä sinne johtava tie, ellei sitä tarvita muihin tarkoituksiin, arvioitava yhtenä kokonaisuutena. Mikäli tie hinnoitetaan erikseen, on vastaava summa vähennettävä sen alueen arvosta, jonka tarkoituksia tie palvelee. Vieläpä siinäkin tapauksessa, että soranmyyntipaikkaan on rakennettu rautatie, on arvioinnissa pidettävä kokonaisuutta silmällä ottaen kuitenkin huomioon, että siirtokelpoiset 
osat rautatierakennuksesta voidaan myydä ja kuljettaa muualle, mikä ei ensin mainitussa tapauksessa ole mahdollista.

Alueluovutusten johdosta menetetyn omaisuuden korvaamisesta annetun lain toimeenpanoasetuksessa syyskuun 2 päivältä 1940 mainittu tonttiarvo muodostaa erittäin tärkeän ja useissa tapauksissa vaikeasti arvioitavan maatalouteen liittyvän etuuden, joka varsinkin asutuskeskusten läheisyydessä voi ratkaisevasti vaikuttaa koko maatalouskiinteistön arvoon. On tunnettua, että maan arvo muodostuu pintaalayksikköä kohden sitä korkeammaksi, mitä pienemmistä tiloista on kysymys. Tämä ilmiö näkyy selvästi tiloista maksettuja kauppahintoja tutkittaessa, kuten esim. Kokkosen (3) laatima tutkimus maan hinnoista Nurmijärven kunnassa osoittaa. Tämä johtuu paitsi kysynnän ja tarjonnan laista myös siitä, että puhdas tuotto ja varsinkin maatalouden antama tulo pinta-alayksikköä kohden tavallisesti alenee viljelmäkoon kasvaessa. Suurissa asutuskeskuksissa, joissa maa-aluetta käytetään melkein yksinomaan rakennuspohjana, maan arvo määräytyy rakennusten antaman tuoton perusteella. Asutuskeskusten läheisyydessä, jossa tontin omistaja voi käyttää aluetta paitsi rakennuspohjana, myös puutarha- ja vihannesviljelyyn, perustuu tontin arvo myös jälkimmäisten tuotannonalojen antamaan ylijäämään, lähinnä viljelijäperheen ansioksi jäävän tulon suuruuteen, joten korkeilla tontin arvoilla on myös taloudellinen perusta niiden subjektiivisten etujen lisäksi, joita omakotialue omistajalleen tarjoaa (4, s. 94). Tonttialueiden suuren taloudellisen merkityksen tähden luovutetulle ja vuokratulle alueelle jääneiden kiinteistöjen arvioinnissa sai kirjoittaja tehtäväkseen laatia tonttialueiden arviointia koskevan ohjeen, joka sisältyi valtiovarainministeriön korvausasiainosaston kiertokirjeeseen arvioimislautakunnille marraskuun 3 päivältä 1945 ja joka on julkaistuna maatalousministeriön asutusasiainosaston julkaisussa n:o 18, ss. 48-52.

Rakennettujen tonttien arvioiminen tulee maatalouden osalta tavallisesti kysymykseen vain tilan talouskeskukseen kuuluvan tontin osalta, jota ei ole käsiteltävä »etuutena», vaan tilaan oleellisesti kuuluvana maankäyttömuotona. Tonttiarvoa joudutaan maataloudessa tai oikeammin maatilataloudessa merkitsemään rakentamattomille alueille, joita arvioimishetkellä käytetään peltona, laitumena, metsämaana jne., mutta joilla on kysyntää esim. huvila- ja asuntotonteiksi. Vaikka tonttiarvo useimmiten edellyttää, että alue sijaitsee luonnonkauniissa ympäristössä ja on sopiva omakotialueeksi tai huviloiden sijoituspaikaksi, osoittaa kokemus tonteiksi ostettavan varsinkin suurten asutuskeskusten vaikutuspiiristä sellaisiakin alueita, joilla tuskin on mitään tonttialueille tyypillisiä erikoisominaisuuksia. Kun tonttialueen käsite on laajentunut siinä määrin, että vilkkaan kysynnän vallitessa melkein mikä tahansa rakentamistarkoituksiin sopiva alue voi taitavan myyjän käsissä muuttua asunto- ja huvila-alueeksi, johdutaan helposti siihen, että laajoja alueita asutuskeskusten ympärillä pidetään »tonttialueina», vaikka asutuskeskus ei milloinkaan voisi laajentua niin suureksi, että kaikki nämä alueet tulisivat tonteiksi käytetyiksi. Mahdollisuus tietyn alueen myyntiin tontteina perustuu siihen, että toiset vastaavanlaisten alueiden omistajat eivät ole halukkaita maataan palstoittamaan, mistä seuraa, että kysyntä pysyy riittävänä tarjontaan verrattuna. Alueen erilaiset käyttömahdollisuudet ovat omiansa vaikeuttamaan arvioinnin suorittamista, 
sillä alueen arvo tonteiksi palstoitettuna voi olla kokonaan toinen kuin esim. maatalousmaaksi käytettynä. Edellistä arvoa ei kuitenkaan voida yleistää, koska riittävää kysyntää ei olisi, mikä taas vaikuttaisi tonttialueidenkin arvoa alentavasti. Ristiriita, joka on olemassa toisaalta maatalousmaan arvon ja saman alueen arvon välillä tonttialueiksi käytettäessä, on selitettävissä vain siten, että samaa omaisuusosaa arvioitaessa voidaan tulla erilaiseen tulokseen riippuen siitä, mitä tarkoitusta varten arviointi suoritetaan (1, s. 95). Maa-aluettakin voidaan käyttää moniin eri tarkoituksiin ja spekulointimielessä käytetyn maan arvo muodostuu toiseksi kuin mitä se tavanomaisen käyttömuotonsa perusteella olisi. Tässä mielessä käyttää esim. KAмpF (2, s. 16) käsitettä „Spekulationsland» omana maankäyttölajinaan. Epäilemättä mahdollisuus myydä suurehkojakin alueita lyhyessä ajassa asunto- tai huvilatonteiksi vaikuttaa yleensä maan arvoa kohottavasti. Kuinka suuri tämä spekulointimahdollisuuden vaikutus on verrattuna "normaaliseen» kysynnän ja tarjonnan vaikutukseen, ei liene erikseen määritettävissä.

Tonttialueita arvioitaessa on tunnettava samat tekijät, jotka tulivat kysymykseen edellä soran- ja hiekanottoalueita käsiteltäessä, nim. alueen laajuus, pinta-alayksikköä kohden saatava myyntihinta sekä alueen todennäköinen myyntiaika. Näiden tekijöiden määrittämisestä riippuu, minkälaiseen tulokseen arvioinnissa tullaan. Vaikka alueen laajuus useimmissa tapauksissa on helposti todettavissa, on kuitenkin harkinnan varaista, kuinka suuret osat esim. tietystä maatalouskiinteistöstä voidaan katsoa tonttiarvoa omaaviksi. Lähinnä tulevat tässä mielessä kysymykseen liikekeskuksen läheisyydessä ja varsinkin teiden varsilla olevat alueet sekä toisaalta luonnonkauniit alueet, kuten järvien ja jokien rannat. Tarkkaa rajaa tonttialueen ja maatalous- tai metsämaan välille ei voida asettaa, eikä se olekaan välttämättömänä edellytyksenä arvioinnin onnistumiselle, koska alueen laajentuessa alueen nykyarvo pinta-alayksikköä kohden alenee lähentyen sen maankäyttölajin arvoa, johon tonttialue kuuluu, ja päinvastoin. Arvioinnissa voidaan siten tulla samaan tulokseen arvioitaessa laajempi alue alhaisemman yksikköhinnan perusteella kuin pieni alue korkeampaa yksikköhintaa käyttäen.

Välttämätön perusta arvioinnin suorittamiseksi on sitä vastoin pinta-alayksiköstä maksettava käypä hinta, joka tavallisesti ilmaistaan neliömetriä kohden. Yksikköhinta voidaan luotettavasti määrittää ainoastaan todella maksettujen kauppahintojen perusteella ottaen kuitenkin huomioon, että jostakin erityisen hyvästä ja halutusta liiketontista maksettu hinta ei suinkaan osoita alueen yleistä hintatasoa. Vertailemalla eri asemassa olevista tonttialueista maksettuja hintoja keskenään voidaan muodostaa hinnoitteluasteikko eri etäisyyksillä ja eri asemassa olevia tonttialueita varten ja tämän asteikon mukaan voidaan määrittää arvioitavasta alueesta todennäköisesti saatava yksikköhinta. Ellei alueelta olisi aikaisemmin myyty ainoatakaan vertailukelpoista tonttialuetta, voidaan lähtökohtana pitää muilla paikkakunnilla vastaavanlaisista alueista maksettuja hintoja. Vaikka tonttialueen yksikköhinta voi tietyn määräalan kaupassa olla erittäin vaikeasti määritettävissä molempia osapuolia tyydyttävällä tavalla, on tämä tekijä tavallisesti helpoimmin ratkaistava niistä perusteista, joita on tunnettava laajoja, rakentamattomia tonttialueita arvioitaessa. Suurimman vaikeuden tonttialueiden 
arvioimisessa muodostaa kolmannen edellä mainitun tekijän eli alueen todennäköisen myyntiajan määrittäminen. Se riippuu erittäin monesta seikasta, kuten läheisen asutuskeskuksen tulevasta kehityksestä ja väkiluvun lisääntymisestä, teiden rakentamisesta ia liikenneyhteyksien kehityksestä, uusien tehtaiden tai valtion laitosten sijoittamisesta paikkakunnalle jne. Jonkinlaisia viitteitä asutuskeskuksen tulevasta kehityksestä saadaan väestötilastosta edellisten vuosikymmenien aikana. Esittämällä väkiluvun kehitys graafisesti voidaan kuvaajan muodosta päätellä väkiluvun tuleva kehityssuunta. Tällainen ennustelu on kuitenkin erittäin epävarmaa, sillä tulevaisuudessa voi esiintyä tekijöitä, jotka kokonaan muuttavat kehityksen suunnan. Seudulle voidaan perustaa esim. teollisuuslaitoksia, jotka lisäävät väkilukua sekä välittömästi että välillisesti ja vaikuttavat nopeasti myös tonttialueiden kysyntään. Toisaalta on useita esimerkkejä pienistä kaupungeista ym. asutuskeskuksista, jotka eivät ole osoittaneet mitään kasvamisen merkkejä vuosikymmeniin. Tonttialueiden tarpeeseen vaikuttaa ratkaisevasti myös asutuskeskuksen omistuksessa olevien alueiden laajuus, asemakaavoitetulla alueella oleva tonttireservi ym. seikat. Varsinkin kaupunkien ja kauppaloiden läheisyydessä olevien tonttialueiden mahdollisimman luotettavan arvon määrittäminen edellyttää perehtymistä näiden keskusten tuleviin laajenemissuunnitelmiin ja -suuntiin, liikenneyhteyksiin yms., joista ympäristössä olevien tonttialueiden kysyntä on riippuvainen. Asutuskeskusten ja liikenneyhteyksien kehitys vaikuttavat myös huvilatonteiksi soveltuvien alueiden kysyntään, vaikkakin vaatimukset etäisyyteen ja valtateihin nähden ovat toiset kuin asunto- ja liiketonttien kohdalla.

Tonttialueita arvioitaessa on joka tapauksessa pyrittävä määrittämään, kuinka pitkän ajan kuluessa kaikki tarkoitukseen soveltuvat alueet todennäköisesti tulisivat myydyiksi normaalisen kysynnän ja tarjonnan puitteissa. Myyntiajasta riippuu, kuinka suuri on alueen nykyarvo tulevaisuudessa saatuihin myyntihintoihin verrattuna. Laskelmissa on yleensä meneteltävä siten, että ajatellaan tonttien myynnin jatkuvan tasaisesti nykyhetkestä siihen ajankohtaan, jolloin alue on kokonaisuudessaan tullut myydyksi, ja lasketaan näin saatujen myyntitulojen nykyarvo edellä esitettyä laskutapaa käyttäen. Myös voidaan käyttää valmiiksi laskettuja kertoimia tai sadanneslukuja, jotka osoittavat, missä suhteessa alueen pääoma-arvo on alueen yksikköhintojen perusteella laskettuun arvoon verrattuna. Käytettäessä $5 \%$ :n korkokantaa saadaan seuraavat kertoimet ja sadannesluvut:

$\begin{array}{rcc}\begin{array}{c}\text { Tonttien myynti- } \\ \text { aika }\end{array} & \text { Kerroin } & \begin{array}{c}\text { Tonttialueen arvo \% } \\ \text { myyntihinnan perus- } \\ \text { teella lasket. arvosta }\end{array} \\ 5 \text { v. } & 4.33 & 86 \\ 10 \text { v. } & 7.72 & 77 \\ 20 \text { v. } & 12.46 & 62 \\ 30 \text { v. } & 15.37 & 51 \\ 40 \text { v. } & 17.16 & 43 \\ 50 \text { v. } & 18.26 & 37 \\ 60 \text { v. } & 18.93 & 32 \\ 75 \text { v. } & 19.48 & 26 \\ 100 \text { v. } & 19.85 & 20\end{array}$


Jos esim. alueelta voidaan myydä tontteja keskimäärin 100.000 markan arvosta vuodessa ja myynnin arvioidaan jatkuvan 30 vuoden ajan, ei alueen nykyarvo ole $30 \times 100.000$ markkaa, vaan $15.37 \times 100.000$ markkaa eli 1.537 .000 markkaa. Sama tulos saadaan laskemalla, että alueen arvo on (pyöristettynä) $51 \% \quad 3.000 .000$ markasta.

Myyntiaika on tekijä, joka vaikuttaa ratkaisevasti tonttialueiden nykyarvoon. Tästä myöskin johtuu, että esim. suurten kaupunkien läheisyydessä, jossa tonttien hinta neliömetriä kohden voi kohota erittäin korkeaksi, suuria maa-alueita myydään hintoihin, jotka ovat vain murto-osa yksityisistä tonteista maksettavien hintojen perusteella lasketusta hinnasta.

Toista korvauslakia sovellettaessa oli vielä ratkaistava eräitä sodan aiheuttamia erikoistapauksia, joilla voi olla teoreettista mielenkiintoa tonttiarvon määrittämiskysymyksiä käsiteltäessä. Tällaisena on mainittava niiden täysin tuhoutuneiden asutuskeskusten vaikutuspiirissä olevien tonttialueiden arvioiminen, joita ei enää jälleenrakennettu entiselle sijoituspaikalleen, vaan siirrettiin uudelle alueelle, jolla jo ennen sodan päättymistä oli myyty tontteja ja suoritettu rakennustöitä. Kun samasta asutuskeskuksesta ei voitu myöntää kaksinkertaista korvausta, ratkaistiin asia siten, että entisen asutuskeskuksen vaikutuspiirissä olevat tonttialueet arvioitiin sellaisena kuin ne olisivat olleet ilman sattunutta tuhoa ja uudesta keskuksesta korvattiin tontteina ainoastaan omistajan omaa käyttöä varten jo hankitut tontit. Muulle alueelle ei uudessa sijoituspaikassa eikä sen lähiympäristössä voitu myöntää erityistä tonttiarvoa.

\section{Loppukatsaus.}

Toisen korvauslain toimeenpanoasetus samoin kuin sitä edeltäneiden korvauslakien toimeenpanoasetukset sekä tulo- ja omaisuusverolaki, johon korvauslaeissa viitataan, edellyttävät erityisenä omaisuuden osana huomioon otettavaksi erilaiset etuudet, joiden arvon määrittämistä maatalouskiinteistöjen yhteydessä edellä olevassa tutkielmassa on käsitelty. Tutkielmassa on rajoituttu käsittelemään ainoastaan eräitä maatalouskiinteistöön kuuluvia oikeuksia, maanparannusaineiden ja niihin verrattavien omaisuusosien käyttöä omaa tarvetta ja myyntiä varten sekä tonttialueiden arviointia.

Etuudet voidaan jakaa kahteen ryhmään sen perusteella, onko ne arvioitava erikseen ja lisättävä saatu arvo maatalouskiinteistön arvoon, vai onko etuuksien arvo sisällytettävä maatalousmaan arvoon, jolloin niiden puuttuminen on otettava huomioon maatalouskiinteistön arvon vähennyksenä.

Etuuksiin, jotka on sisällytettävä maatalousmaan arvoon, on luettava esim. tilalle välttämättömät maanparannusaineiden ottopaikat. Samaan ryhmään on luettava useimmat isossajaossa tai tiloja ositettaessa perustetut rasiteoikeudet, kuten oikeus tiehen, karjanajoon, vesipaikkaan tai veden johtamiseen, sillä tällaiset oikeudet on katsottava välttämättömiksi tilan käytölle eikä niistä aiheudu tilalle suoranaista tuloa. Etuuksien puuttumisen on katsottava alentavan kiinteistön 
arvoa ja arvon vähennys on määritettävä laskemalla, kuinka paljon puutteen poistaminen aiheuttaisi kustannuksia, tai pääomittamalla puutteen aiheuttamat vuotuiset kustannukset tai tuoton menetykset.

Tuloa tuottavien etuuksien arvo on määritettävä niistä saatavan vuotuisen keskimääräisen puhtaan tuoton perusteella. Arvioitaessa raaka-ainealuetta tai tarveainevarastoa, jonka määrä on rajoitettu, on arvioinnissa otettava huomioon myyntikelpoisen aineksen määrä, yksikköhinta ja todennäköinen myyntiaika. Milloin myynnin voidaan edellyttää jatkuvan vähintään 60 vuotta tai sitä pitemmän ajan, voidaan etuuden pääoma-arvo suurta virhettä tekemättä määrittää pääomittamalla vuotuinen puhdas tuotto rajattoman ajan kestävänä. Muissa tapauksissa on etuuden pääoma-arvo laskettava rajoitetun ajan kestävän tuoton nykyarvona.

Soran ja hiekan myyntialueita arvioitaessa on otettava huomioon vain myyntikelpoisen tuotteen määrä, jota laskettaessa on pintamaan, kivien yms. osuus vähennettävä sekä lisäksi vähennettävä soran tai hiekan luonnollisen kaltevuuden tähden sora- tai hiekkakaivannon seinämille jäävä ainesmäärä.

Arvioitaessa teollisuuden käyttämiä raaka-ainealueita on arvo määritettävä alueista todellisuudessa saatujen tai varmuudella saatavien tulojen perusteella. Suuretkaan raaka-ainevarastot, joilla ei ole kysyntää, eivät muodostu etuuksiksi, joiden arvo olisi erikseen otettava huomioon. Erityisesti on varottava arvioimasta suuria raaka-ainevarastoja niiden kokonaismäärän perusteella ottamatta huomioon varaston myyntiin vaadittavan ajan pituutta ja sen vaikutusta tulevaisuudessa saatavien tulojen nykyarvoon.

Tonteiksi sopivia alueita arvioitaessa on otettava lähtökohdaksi vastaavanlaisista alueista maksettavat käyvät hinnat, alueen laajuus ja todennäköinen myyntiaika, jota arvioitaessa on otettava huomioon tonttien kysyntään ja tarjontaan vaikuttavat tekijät. Tonttialueen arvo voidaan määrittää rajoitetun ajan kestävän tuoton nykyarvona.

Tonttialueiden arvo on huomattavasti riippuvainen niiden käyttötarkoituksesta ja laajoillakin alueilla voi suurten asutuskeskusten läheisyydessä olla palstoitusmahdollisuuden aiheuttama spekulointiarvo, joka on korkeampi kuin vastaavanlaisen alueen arvo keskimäärin tulee olemaan.

Toista korvauslakia sovellettaessa jouduttiin arvioimaan tonttialueita sellaisten asutuskeskusten alueella ja ympäristössä, jotka olivat tuhoutuneet ja päätetty rakentaa uuteen sijoituspaikkaan. Tällöin otettiin huomioon entinen sijoituspaikka sellaisena kuin se olisi ollut ilman tuhoutumista ja uudesta sijoituspaikasta korvattiin vain omistajan omaa käyttöä varten hankitut uudet tontit. 


\title{
KIRJALLISUUTTA.
}

(1) Aereboe, Friedrich 1919. Die Beurteilung von Landgütern und Grundstücken. Berlin.

(2) KampF, R. 1916. Der Grundstückswert. Handbuch zur Ermittlung des Werts ländlicher und städtischer Grundstücke. I-II. Berlin.

(3) Kokkonen, P. 1940. Maan »käypä hinta» Nurmijärven kunnassa vuosina $1934-38$. Maataloustiet. Aikakauskirja, 12, p. 98-141.

(4) KäRNä, MAUno 1948. Tonttimaan arvon määräämisestä. Maanviljelysinsinööriyhdistyksen vuosikirja 1948, p. 93-97. Helsinki.

(5) Lisäyksiä asutusasiainosaston julkaisuissa n:o 7 ja 13 annettuihin maanhankintalain toimeenpanoohjeisiin. Maatalousministeriön asutusasiainosaston julk. N:o 18. Helsinki 1947.

(6) (MäKI, AntTI 1945). Maatalousvahinkojen arvioimisperusteet toista korvauslakia sovellettaessa. Valtiovarainministeriön ohjeita arvioimislautakunnille. III. Helsinki.

(7) Talvitie, Y. 1945. Kemiallisen teollisuuden kotimaiset raaka-aineet. Kemian keskusliiton julk., 6, N:o 2, 1945. Helsinki.

(8) Teknillinen käsikirja. III muutettu ja laajennettu painos. Jyväskylä 1929.

\section{S U M M A R Y.}

\section{ON THE VALUATION OF BENEFITS CONNECTED WITH AGRICULTURE IN THE APPLICATION OF THE SECOND COMPENSATION ACT.}

\author{
AntTi Mäki.
}

\section{Institute of Agricultural Economics, Helsinki University.}

To provide compensation for the economic losses incurred in the 1939-1944 wars, several laws were passed in Finland, including the Compensation Acts of 1940 and 1942, and the so-called Second Compensation Act of 1945. The article deals with the valuation of the benefits attached to agricultural real estate, primarily as regards the application of the Second Compensation Act. The benefits include a number of different rights of enjoyment and income-earning rights, and certain parts of property that cannot be included under any other heading in an agricultural estate.

The benefits can be divided in to two groups according to whether they should be valued separately and the obtained value added to the value of the agricultural estate, or whether the value of the benefits should be considered as included in the value of the agricultural land, in which case their absence must be allowed for as a reduction in the value of the agricultural estate.

The first group should include e.g. sources of soil improvements essential to the farm's own use, and the rights of encumbrance belonging to the farm, i.e. right of way, water rights or driving rights for cattle, as such rights must be considered indispensable to the continued running of the farm. The absence of the benefits reduces the value of the estate, and the reduction in value must be defined by calculating the cost of remedying the deficiency.

Income-earning benefits must be valued on the basis of the average annual pure yield obtained. In the valuation of an area containing raw materials, of which the quantity is limited, the quantity of saleable material, unit price and probable time of sale must be considered. Whenever sales can be assumed to continue for 60 years, the present-day value of the benefit can be obtained, with no serious inaccuracy, by capitalising the annual pure yield in terms of its continuing for an unlimited time. In other cases the present-day value of the benefit must be calculated by allowing for its limited period of duration and by discounting the yield values to be obtained in this period in terms of the present moment. 
In valuation of the sales of gravel, sand, clay etc. sources, the quantity of saleable material only should be considered, and in the calculations the precentage of covering soil, stones, etc., must be deducted. In addition, the natural slope of the gravel must be taken into consideration, for it causes a considerable quantity of material to be left against the walls of a deep gravel or sand pit, material which cannot be included in the saleable material.

In valueing areas suitable for housing, business or industrial plots, the real sale and purchase prices of similar areas must be taken as the basis, plus the extent of the area and the probable annual demand for plots. The value of a plot can be defined as the present-day value of a yield continuing for a limited time. If the area is very large its value can be computed by capitalising the average annual pure yield obtained from the sale of plots.

The value of plot is greatly dependent on the potential use of the plots, and extensive areas in the neighbourhood of centres of population may have a speculative value higher than the possible estimate of the average value of all similar areas.

In applying the Second Compensation Act it was also necessary to value plot areas in the neighbourhood of and within such centres of population as had been destroyed and which were designed to be re-built in an entirely new location — which latter was also ceded as a result of the war. In such a case the old location in its entirety was assumed to be in the state it would have been in 1944 undestroyed, and in the new location only such small areas were valued as plot land as had been bought at plot price for the owner's personal use. As regards the rest of the area, no special value was awarded the land as prospective plots. 